\title{
A new Early Pleistocene species of Nothofagus and the climatic implications of co-occurring Nothofagus fossils \\ Gregory J. Jordan
}

School of Plant Science, University of Tasmania, GPO Box 252-55, Hobart, Tas. 7001, Australia. email: greg.jordan@utas.edu.au

\section{Abstract}

A new species of Nothofagus, N. pachyphylla, is proposed based on fossils from Early Pleistocene sediments at Regatta Point, western Tasmania. This extinct species occurred for some time with its sister species, $N$. cunninghamii, which is still extant in Tasmania. The fossil leaves of $N$. cunninghamii in the Regatta Point sediments are all very small and are only consistent with leaves from cold climate extant populations of this species. The fossil leaves of other taxa in these sediments are also mostly at the small (and cool climate) end of the range of the leaves of their extant relatives. These data provide corroborating evidence for floristically based inferences of colder than modern palaeoclimates for this fossil site. The co-occurrence of small and large leaved sister species is paralleled in a number of modern Tasmanian rainforest genera.

\section{Introduction}

Sediments at Regatta Point, western Tasmania, contain the only diverse Early Pleistocene macrofloras in Australia (Jordan 1997b). Rich macrofloras from this time are rare worldwide, but are significant because the Late Pliocene/Early Pleistocene was a period of transition from Tertiary floras dominated by extinct species to floras of essentially modern composition (Traverse 1982; Macphail et al. 1993). Significantly, the Regatta Point floras are excellent examples of anomalous assemblages: that is, there are strong contrasts between the climatic and ecological ranges of the near living relatives of co-occurring fossils. The greatest contrasts are in temperature ranges, the living relatives of some taxa (e.g. Microcachrys tetragona (Hook.) Hook.f., Athrotaxis) only occur naturally in cool to cold climates whereas others (e.g. broad leaved Lauraceae, Rubus nebuloides G. J. Jord.) have living relatives restricted to warm climates (Macphail et al. 1993; Jordan 1997a).

Such anomalous assemblages occur elsewhere in Late Tertiary and Early Pleistocene sediments (e.g. Axelrod 1988), and understanding their cause is important if floristic data is to be used to determine past climates (Jordan 1997a). Macphail et al. (1993) and Jordan (1997a) attributed the contrasts at Regatta Point to extinct species or populations with climatic limits outside the range of their extant relatives. In contrast, Kershaw and McGlone (1995) attributed the contrasts in conifers to palaeoclimates with no modern analogue. Axelrod (1988) used a special case of this argument by attributing similar anomalies in North American conifers to greater climatic equability in the Tertiary, so that there was less summer drought and less severe frost in winters. Understanding the climate at the time of deposition of the fossil assemblages will help in determining which taxa were living outside the climatic range of their living relatives, which in turn will help in determining which of the hypotheses listed above is most likely.

One apparent anomaly in the Regatta Point floras was the significantly high variability in, and bimodal distribution of, leaf length in fossils ascribed to Nothofagus cunninghamii (Hook.) Oerst. by Hill and Macphail (1985) (Jordan and Hill 1994). Jordan and Hill (1994) concluded that either two related species co-occurred near Regatta Point, of which at least one is now extinct, or the variability within populations of $N$. cunninghamii was greater in the past, possibly due to mixing of warm and cool climate floras. The presence of a highly variable species of Nothofagus would be difficult to interpret climatically, but the presence of a normal population of N. cunninghamii and an extinct species would be much easier, especially in the light of the close relationship between leaf size and climate found in extant populations of N. cunninghamii by Jordan and Hill (1994). 
The present work resolves the anomaly in Nothofagus leaf size by showing that the large form falls outside the extant morphological range of $N$. cunninghamii, and a new species is proposed. No climatic inferences are drawn from this new species, but the remaining fossil leaves fall within the range of extant $N$. cunninghamii so climatic inferences are made, based on the variation among extant populations of $N$. cunninghamii.

\section{Materials and Methods}

\section{Fossil Site}

The complex Pleistocene sediments at Regatta Point in western Tasmania (Figure 1) were described by Hill and Macphail (1994), Macphail et al. (1993) and Jordan et al. (1995). The fossils occur in mudstone and sandstone clasts embedded in gravels. The gravels are probably of Middle Pleistocene age, but the clasts containing the fossils are older. This paper is concerned with the Early Pleistocene fossil floras referred to as RPU1 and RPU2 by Jordan $(1992,1997 b)$. The species in the RPU2 flora were almost certainly contemporaneous (Jordan 1997a,b), while the RPU1 fossil flora is a composite of floras which may be from a range of ages. Some of the macrofossils may have been transported some distance before deposition because the mudstones containing the RPU2 and RPU1 floras appear to be fluvial. Although Macphail and Hill (1985) suggested that the clasts were carried on rafts of glacial outwash, the clasts could easily have been produced by the far more common process of erosion and collapse of a river bank. The clasts are, therefore unlikely to have been transported far.
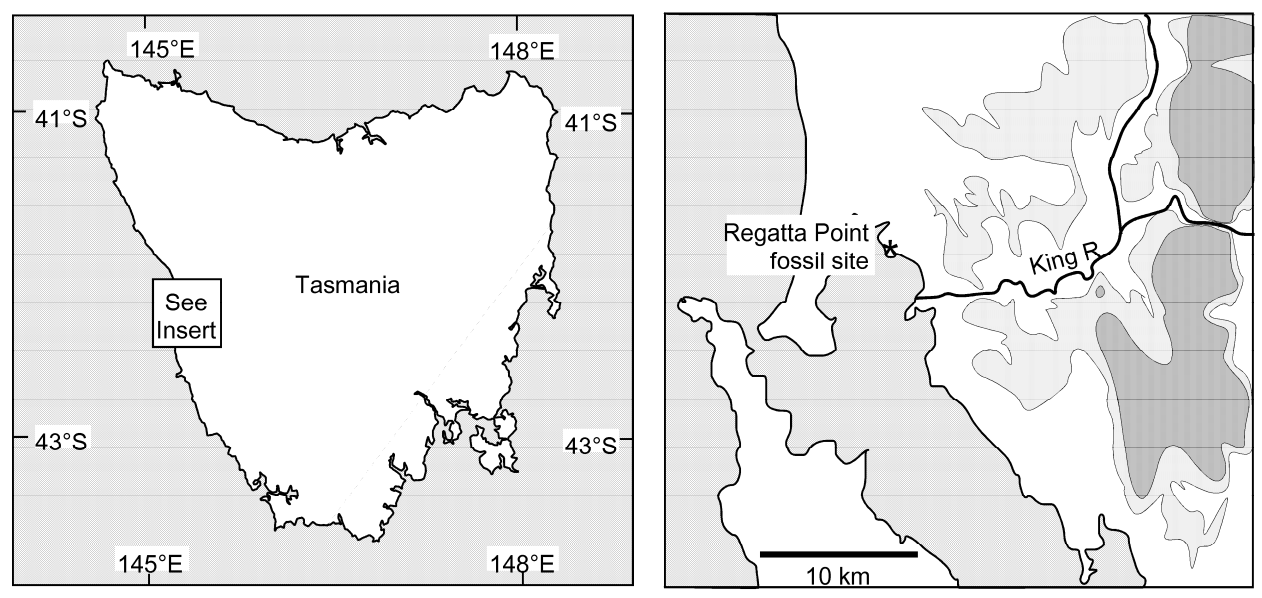

Figure 1. Western Tasmania with an inset showing the location of the Regatta Point fossil site. Light shaded areas are above $200 \mathrm{~m}$ above sea level, dark shaded areas are above $400 \mathrm{~m}$. The King River is constrained by hard, quartzitic rock up to its mouth so that the King River is unlikely to have created the Regatta Point sediments without several meanders providing filters for leaves transported from mountains. No other local drainages include high areas.

\section{Leaf Extraction and Processing}

Fossil leaves were extracted from the sediments by either macerating blocks of mudstone in warm, dilute $\mathrm{H}_{2} \mathrm{O}_{2}$ for a few hours, or in approximately $20 \% \mathrm{HF}$ for one or two weeks, or by splitting the mudstone blocks (Hill and Jordan 1994). The RPU1 and RPU2 collections each contained approximately 1000 Nothofagus leaves and leaf fragments extracted in these ways. Some leaves were immersed in dilute $\mathrm{H}_{2} \mathrm{O}_{2}$ with a trace of tetrasodium pyrophosphate until they were clear enough to observe the venation. Cuticles were prepared by immersing fossil leaf fragments in $\mathrm{Cr}_{2} \mathrm{O}_{3}$ until the mesophyll had oxidised. The cuticles were then stained with $0.3 \%$ aqueous Safranin $\mathrm{O}$ for approximately 10 minutes and mounted on glass slides in phenol glycerin jelly for transmitted light microscopy. 


\section{Leaf Descriptions}

Fossils were compared with a large collection of herbarium specimens, cuticles and cleared leaves of fossil and extant species housed in the Department of Plant Science, University of Tasmania. In particular, this collection includes several hundred specimens from more than 100 populations from throughout the range of extant Nothofagus cunninghamii. Descriptions of leaf architecture and cuticular anatomy follow Hickey (1979) and Dilcher (1974) respectively.

\section{Systematics}

Family Fagaceae

Nothofagus Blume

Subgenus Lophozonia

Nothofagus pachyphylla G. J. Jord. sp. nov. (Figures 2 - 8)

Diagnosis. Leaves mostly more than $10 \mathrm{~mm}$ long, broadly ovate, elliptical or orbicular, apex rounded, base rounded, margins shallowly crenate, thickened. Stomata restricted to broad areoles. Solitary unicellular trichomes with hollow bases surrounded by small, raised epidermal cells present.

Description. Leaves 8 - (12) - $25 \mathrm{~mm}$ long, mostly bilaterally symmetrical, 8 -(9) - $20 \mathrm{~mm}$ broad, ovate to very widely ovate, or suborbiculate to orbiculate, apex rounded, base rounded to roundedcordate, widest point mostly about $1 / 4$ of the way up the leaf, margins thickened, sometimes narrowly recurved, shallowly crenate. Midrib stout, straight and unbranched; midrib, secondary and tertiary veins prominent on abaxial surface, midrib and secondary veins depressed on adaxial surface; venation craspedodromous with strong secondary veins at about $45^{\circ}$ from the midrib, alternate apart from one basal sub-opposite pair, straight or weakly curved apically, often branched, with the weaker, more obtuse branch leading to a more basal tooth; basal secondary veins usually less acute; tertiary veins predominantly orthogonal reticulate, occasional percurrent tertiary veins present; fourth order veins orthogonal reticulate, forming well developed areoles; areoles small, about $0.3 \mathrm{~mm}$; simple or branched veinlets in most areoles; fimbrial vein absent. Petioles short, 1-3 mm long, about 0.8 - $1 \mathrm{~mm}$ wide, solid, often curved to one side.

Adaxial surface with almost isodiametric epidermal cells with slightly undulate margins, $10-15 \mu \mathrm{m}$ long; glandular trichomes occasional, 25 - $40 \mu \mathrm{m}$ wide; conical unicellular trichomes abundant, very variable in length but mostly less than $30 \mu \mathrm{m}$ long, with basal cells 15 - 25 - (35) $\mu \mathrm{m}$ wide with thick periclinal walls. Abaxial surface with similar epidermal cells to adaxial surface except slightly larger, 20-25 $\mu \mathrm{m}$; stomata cyclocytic, restricted to areoles, randomly oriented, about $20 \mu \mathrm{m}$ long; occasional giant stomata about $50 \mu \mathrm{m}$ long present outside areoles; glandular trichomes common; conical trichomes similar to those on adaxial surface common on veins, but often larger, sometimes formed from more than one epidermal cell; large hollow, cylindrical, broad based, solitary unicellular trichomes surrounded by small, raised epidermal cells occasional on midrib and secondary veins, about 20 - $25 \mu \mathrm{m}$ wide, up to $150 \mu \mathrm{m}$ long, bases 30 - $40 \mu \mathrm{m}$ wide; trichomes rare within areoles.

Type specimen: RPU 4596.

Type locality: The Early Pleistocene mudstone clast containing the RPU2 flora, 500m south of Regatta Point, western Tasmania.

Distribution: Known only from various clasts in the Pleistocene gravels at Regatta Point.

Etymology. To note the thick leaves.

Specimens examined: RPU 002, 010 - 012, 4597- 4676. 

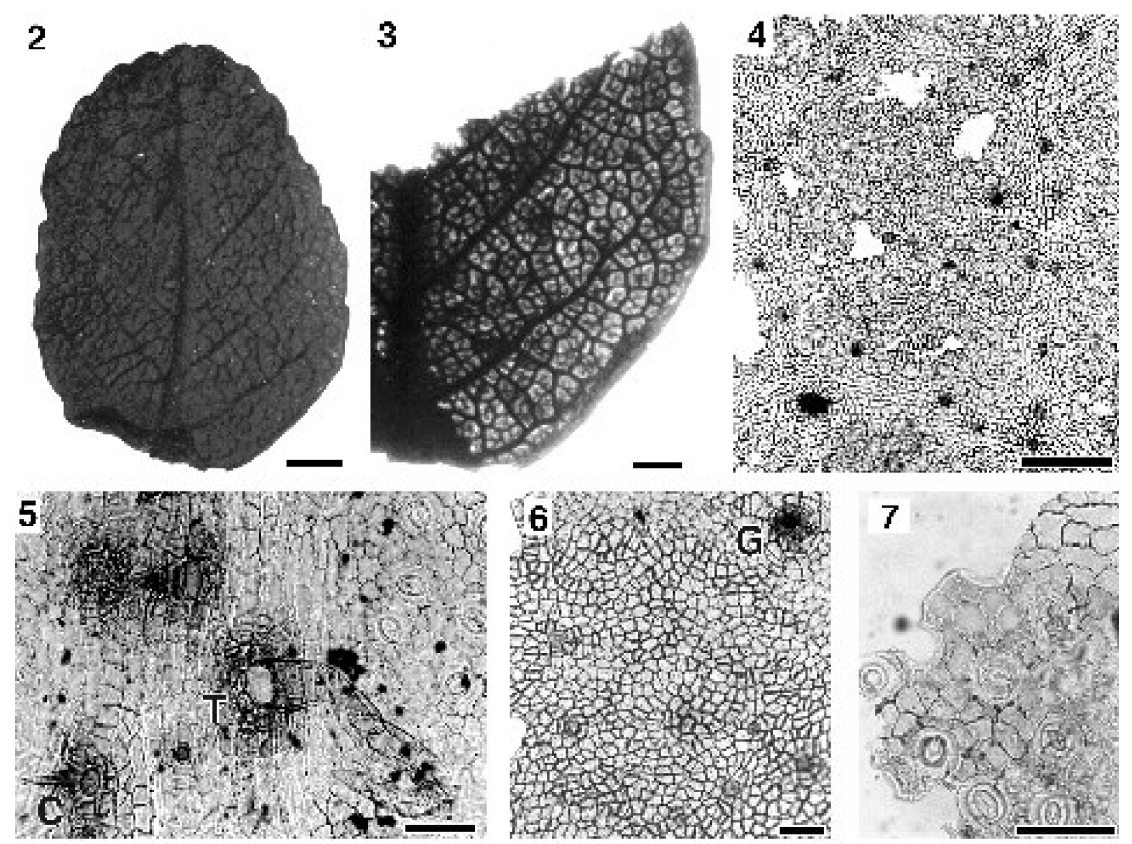

B
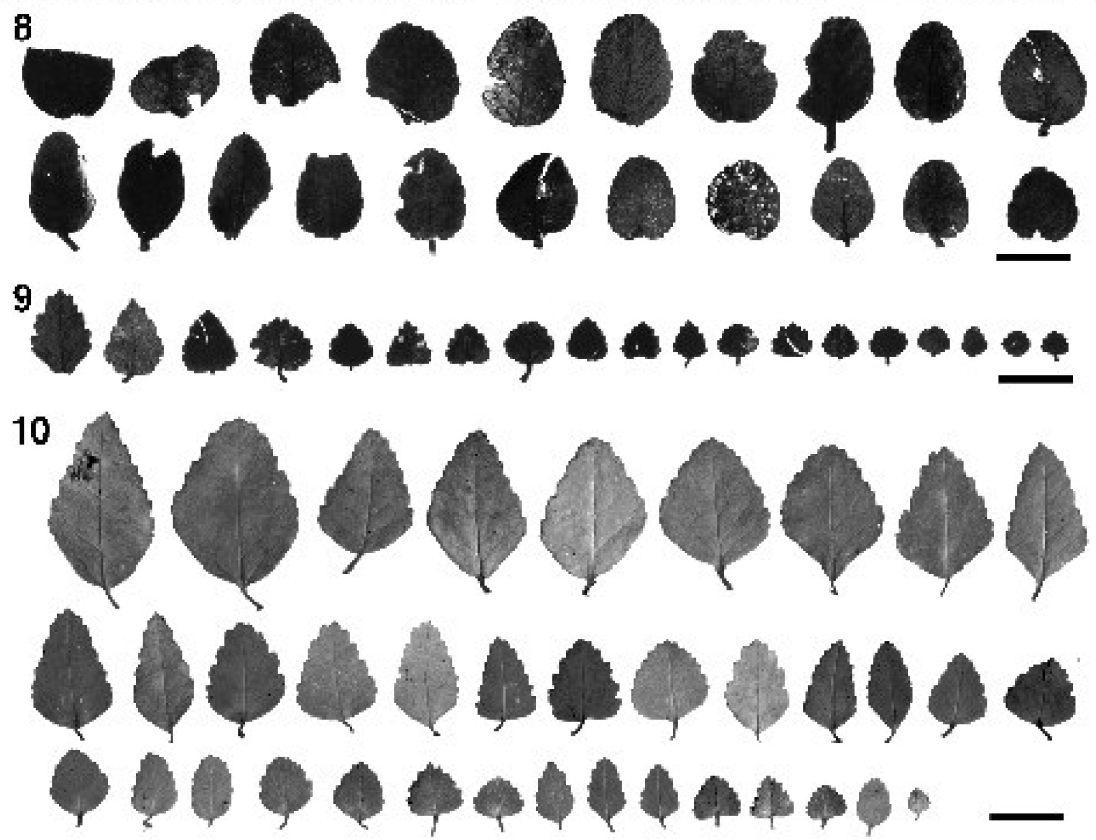

Figure 2. Holotype of Nothofagus pachyphylla G. J. Jord. sp. nov. (RPU 4596). Scale bar $=2 \mathrm{~mm}$.

Figure 3. Cleared portion of the holotype of $N$. pachyphylla. Note the lack of a fimbrial vein. Scale bar $=1 \mathrm{~mm}$. Figure 4. Cuticle of the abaxial surface of the holotype of $N$. pachyphylla. showing stomata restricted to an areole. Scale bar $=200 \mu \mathrm{m}$.

Figure 5. Cuticle of the abaxial surface of N. pachyphylla (RPU 4598) showing a hollow based solitary unicellular trichome $(\mathrm{T})$ and a conical trichome with an enlarged base $(\mathrm{C})$. Scale bar $=50 \mu \mathrm{m}$.

Figure 6. Cuticle of the adaxial surface of the holotype of N. pachyphylla showing the base of a glandular trichome (G). Scale bar $=50 \mu \mathrm{m}$.

Figure 7. Cuticle of the abaxial surface of the holotype of $N$. pachyphylla showing the randomly oriented cyclocytic stomata. Scale bar $=50 \mu \mathrm{m}$.

Figure 8. Representative leaves of $N$. pachyphylla from the Regatta Point sediments. Scale bar $=10 \mathrm{~mm}$.

Figure 9. Fossil N. cunninghamii leaves from the Regatta Point sediments. Compare these leaves with Fig. 10. Scale bar $=10 \mathrm{~mm}$.

Figure 10. Extant $N$. cunninghamii leaves covering the morphological and geographical range of this species. Unlike $N$. pachyphylla, the large extant leaves are distinctly serrate with acute apices. Scale bar $=10 \mathrm{~mm}$. 

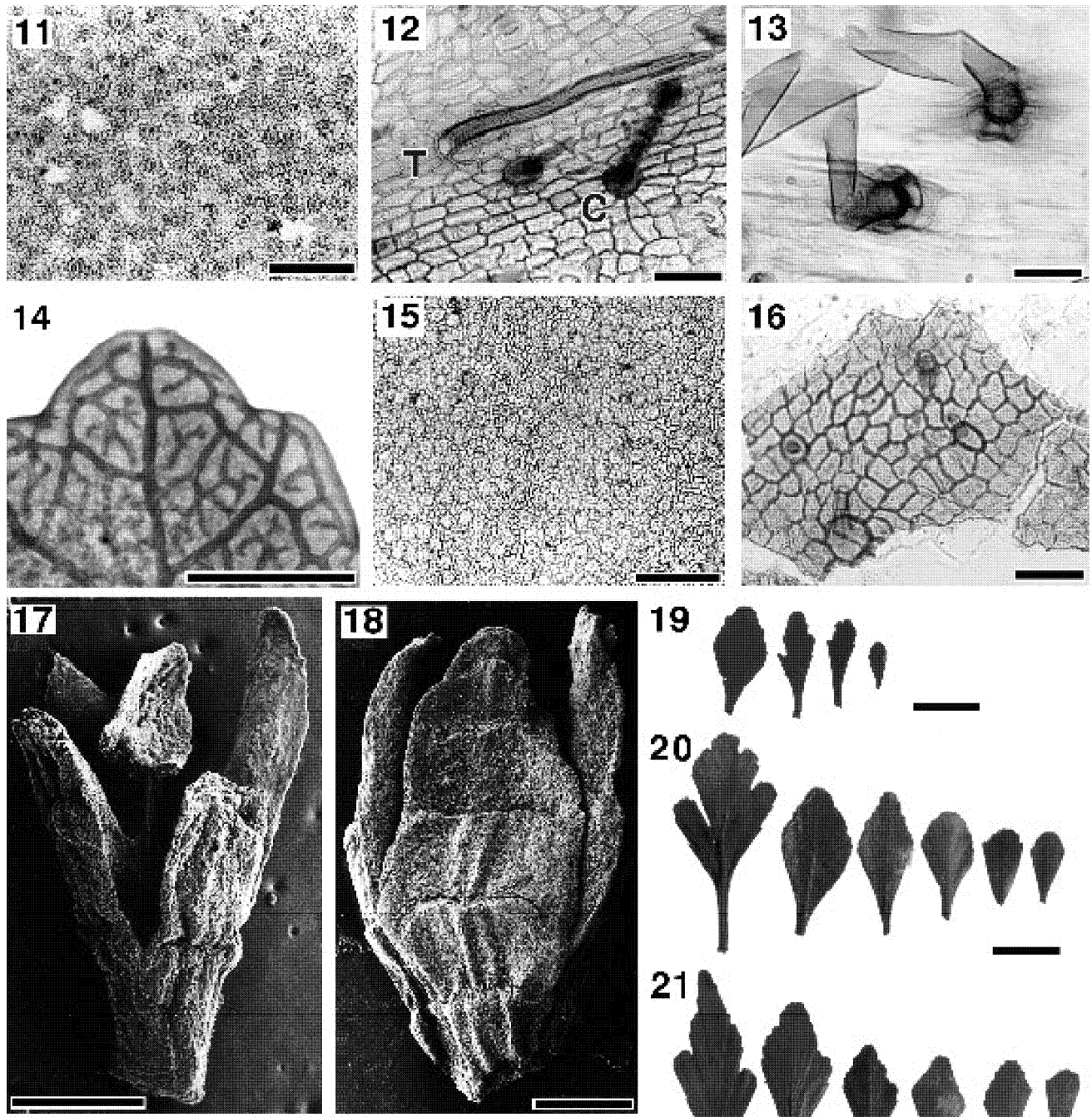

19
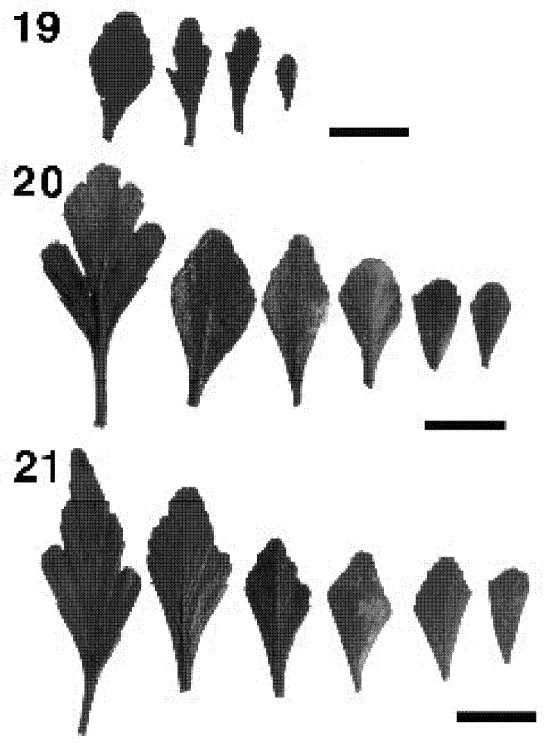

Figure 11. Cuticle of the abaxial surface of extant $N$. cunninghamii showing the lack of areolation. Compare with Figs 4 and 15 . Scale bar $=200 \mu \mathrm{m}$.

Figure 12. Cuticle of the abaxial surface of extant $N$. cunninghamii showing a hollow based solitary unicellular trichome (T) and conical trichomes with an enlarged base (C). Compare with Fig. 5 and 13. Scale bar $=50 \mu \mathrm{m}$.

Figure 13. Cuticle of the abaxial surface of extant $N$. pumilio showing two solitary unicellular trichomes with solid bases. Compare this with Figs 5 and 12. Scale bar $=50 \mu \mathrm{m}$.

Figure 14. Apex of a cleared $N$. cunninghamii leaf showing the lack of a fimbrial vein. Scale bar $=1 \mathrm{~mm}$.

Figure 15. Cuticle of the abaxial surface of a fossil $N$. cunninghamii leaf from Regatta Point showing the lack of areolation. Compare with Figs 4 and 11. Scale bar $=200 \mu \mathrm{m}$.

Figure 16. Cuticle of the adaxial surface of a fossil N. cunninghamii leaf from Regatta Point showing some conical trichomes. Compare with Fig. 5 and 12. Scale bar $=50 \mu \mathrm{m}$.

Figure 17. Fossil Nothofagus cupule from Regatta Point comparable to extant N. cunninghamii. Scale bar $=1 \mathrm{~mm}$.

Figure 18. Fossil Nothofagus cupule from Regatta Point possibly of $N$. pachyphylla. Scale bar $=1 \mathrm{~mm}$.

Figure 19. Fossil phylloclades of Phyllocladus aspleniifolius from the Early Pleistocene Regatta Point sediments. Scale bar $=10 \mathrm{~mm}$.

Figure 20. Phylloclades of $P$. aspleniifolius from leaf litter from a site $500 \mathrm{~m}$ higher than Regatta Point. Scale bar $=10$ $\mathrm{mm}$.

Figure 21. Phylloclades of $P$. aspleniifolius from leaf litter from a site $900 \mathrm{~m}$ higher than Regatta Point. Scale bar $=10$ $\mathrm{mm}$. 


\section{Results}

Nothofagus pachyphylla (Figs 2 - 8) can be assigned to Nothofagus with confidence based on a combination of characters. It shows many features which occur within the genus, including two distinctive trichomes types (the conical and glandular trichomes of Hill and Read 1991), cyclocytic stomata, craspedodromous venation with some percurrent tertiary veins, evergreen habit (see below), margins with only one or two teeth per secondary vein. No other extant genus is known to have all these characteristics. Some Betulaceae species have most of them, but are deciduous and have leaves with multiple teeth.

The N. pachyphylla leaves (Fig. 8) are distinct in size and shape from the other Nothofagus leaves in the Regatta Point sediments (Fig. 9). Nothofagus pachyphylla has leaves as large as big leaved extant populations of its sister species, N. cunninghamii (G. J. Jordan and R. S. Hill unpublished data) (Fig. 10), but differ in margin type, shape and cuticular morphology. In N. pachyphylla leaves the margins are crenulate and often recurved and the apices are rounded and obtuse (Fig. 8), whereas large $N$. cunninghamii leaves have distinctly serrate, plane margins and more or less triangular and acute apices (Fig. 10). Although isolated, abnormal $N$. cunninghamii leaves may resemble $N$. pachyphylla in shape, the fossils appear to come from a significant and persistent population because they occur in most clasts at Regatta Point. Like all extant species of Nothofagus except N. cunninghamii (Fig. 11) (Hill and Read 1991; G. J. Jordan unpublished data) the stomata of $N$. pachyphylla are restricted to areoles (Fig. 4). It has large, thin walled trichomes with hollow bases. They are probably homologous to the large, thin walled, hollow based trichomes of Betulaceae and subgenus Lophozonia (Fig. 12; the solitary unicellular trichomes type C of Hill and Read 1991) but differ in being surrounded by several raised, rounded, thickened epidermal cells, that sometimes appear to be biseriate (Fig. 5). They show some resemblance to the solitary unicellular trichome type D of Hill and Read (1991) found only in N. pumilio (Poepp. \& Endl.) Oerst. (Fig. 13), but those in N. pumilio have solid bases. Nothofagus pachyphylla is distinct from other extant or fossil species of Nothofagus in a variety of ways. Depending on the species these include the presence of the trichomes described above, simple, rounded teeth, conical and glandular trichomes, and randomly aligned stomata; and the lack of a fimbrial vein, T-shaped pieces of cutin at the stomatal poles or certain trichomes (SUTT A of Hill and Read 1991).

Nothofagus pachyphylla is likely to have been evergreen because its leaves are thick, with thick adaxial and abaxial cuticles, and show no sign of the concertina-like folds produced by plicate vernation which is characteristic of deciduous Nothofagus leaves (Philipson and Philipson 1988; Hill and Read 1991). Based on the habitats of its relatives, N. pachyphylla was probably a temperate rainforest tree or a montane shrub.

The small leaves of Nothofagus (Figs 9, 15 and 16) occurring with N. pachyphylla are consistent with some small leaves of $N$. cunninghamii (Figs. 10,11) apart from having unusually high stomatal densities. In particular, their stomata are uniformly distributed across the lamina, which occurs in $N$. cunninghamii and no other species of Nothofagus, or in Betulaceae or Fagus which Hill and Jordan (1993) and Manos (1997) used as outgroups for the genus. They are, therefore, assigned to $N$. cunninghamii. All other Pleistocene macrofossils of Nothofagus from Tasmania are consistent with either $N$. cunninghamii or the other extant Tasmanian species, $N$. gunnii (Colhoun and van der Geer 1987; Colhoun et al. 1989; Fitzsimons 1990; Jordan et al. 1991; Jordan 1992; Fowler 1993; Bresnehan 1993; Jordan and Hill 1994; Jordan et al. 1995; Rowell 1995). There is no discernible difference between the $N$. pachyphylla leaves in the RPU2 flora and those in the RPU1 flora. This is also true for the $N$. cunninghamii leaves in the two floras.

Two types of Nothofagus cupule occur in the Regatta Point sediments (Figs. 17 and 18). Both are consistent with Nothofagus subgenus Lophozonia. One (Fig. 17) has narrow valves, and is 
consistent with small extant $N$. cunninghamii cupules (Fig. 17). The other (Fig. 18) is larger and has broader valves than is normal for $N$. cunninghamii. Jordan (1992) suggested that these might be $N$. gunnii, however N. gunnii cupules have robust lamellae (Hill and Read 1991), of which there are no sign on the fossils. The fossils therefore may be those of N. pachyphylla.

\section{Discussion}

The separation of the Regatta Point Nothofagus fossils into an extinct species with large leaves, and a population of the extant Tasmanian species, $N$. cunninghamii, with small leaves data discounts Jordan and Hill's (1994) hypothesis of greater variability in leaf size in the Early Pleistocene. Neither N. pachyphylla nor the fossil N. cunninghamii at Regatta Point are more variable in leaf length than living populations. However, the recognised Tasmanian Tertiary Nothofagus species still have highly variable leaves (see Figs 5 and 6 in Scriven and Hill 1996), and whether this is due to co-occurring species with strongly overlapping leaf form, or due to high within species variablity remains unknown.

The Nothofagus cunninghamii leaves in the Regatta Point sediments are entirely consistent with those of a very small leaved extant population of this species. The only extant populations of $N$. cunninghamii with mean leaf lengths as small as this grow in areas with mean temperature of the warmest three months of $6-10^{\circ} \mathrm{C}$ (the small leaf size class in Fig. 8c of Jordan and Hill 1994). This is $6-10^{\circ}$ cooler than the summer temperatures at Regatta Point. Taphonomic effects may have caused biases in the size of the fossil leaves: Jordan and Hill (1994) documented five comparisons between forest floor litter samples (like those used to create the model used here) and leaves in aquatic samples (which are more equivalent to fossil samples). These taphonomic differences in leaf size would cause the model to underestimate summer temperature by $-1-3{ }^{\circ} \mathrm{C}$. Transport from colder environments could increase this bias, especially since $N$. cunninghamii is strongly represented in stream litter samples (Carpenter and Horwitz 1988; Jordan 1992). However this bias is likely to be small (less than about $2^{\circ} \mathrm{C}$, assuming a lapse rate of $0.65^{\circ} \mathrm{C} 100 \mathrm{~m}^{-1}$ ), because the leaves are unlikely to have been transported from any place more than $300 \mathrm{~m}$ above sea level (Fig. 1; Jordan and Hill 1994). Thus, underestimates of temperature due to taphonomic causes are unlikely to be more than about $5^{\circ} \mathrm{C}$. The affects on the estimates of factors such as changes in atmospheric $\mathrm{CO}_{2}$ concentration and evolution within the species are unknown, but, allowing for taphonomic biases, the fossils are consistent with summer temperatures significantly colder than now (at least $1^{\circ}$ colder, probably more). Also, summer temperature is the closest known correlate for leaf length in $N$. cunninghamii, but may not be the true controlling factor. Nevertheless the small leaf size is difficult to explain in any but a cold climate, so that these fossils provide independent supporting evidence for Jordan's (1997a) floristically based inferences that climates at the time of deposition of the sediments were at least $1^{\circ} \mathrm{C}$ colder than they are now.

The inference of a cool climate at Regatta Point is further supported by fossils of other extant Tasmanian species in the sediments which mostly have leaves consistent in size with subalpine populations of the extant species, although the association between leaf size and temperature is not as clear in these species as it is in N. cunninghamii. For example, the fossil phylloclades of Phyllocladus aspleniifolius (Labill.) Hook.f., (Figs 19 - 21) are very small, and the Eucryphia leaves are consistent in size with those of E. milliganii Hook. f. which is restricted to cooler climates than modern Regatta Point, and small leaved populations of E. lucida (Labill.) Baill. (Hill 1991). The extinct fossil species with warm climate relatives also strongly tend to be small leaved.

Myrtaceaephyllum pleistocenicum G. J. Jord., Rubus nebuloides G. J. Jord., Quintinia tasmanensis G. J. Jord. and Laurophyllum australum G. J. Jord. all have small leaves compared to their near living relatives (Jordan 1997b). The inference of a cool climate is significant because it supports Jordan's $(1997 a, b)$ suggestion that the fossils at Regatta Point with warm climate extant relatives were mainly extinct cool climate species. 
The climatic inferences that can be drawn from Nothofagus pachyphylla are limited because it is an extinct species (see Jordan 1997a). The large leaves of $N$. pachyphylla are consistent Jordan's $(1997 a, b)$ climatic and floristic interpretations of the Regatta Point floras. The co-occurrence at Regatta Point of large and small sister species of Nothofagus is paralleled in extant Tasmanian rainforest species of several genera (Jordan and Hill 1994). Some examples are the pairs of sister species, Eucryphia milliganii and E. lucida (Taylor and Hill 1996), Athrotaxis selaginoides and A. cupressoides, and probably Richea scoparia and $R$. pandanifolia, which often grow together or in adjacent montane rainforest communities.

Although the cause of the extinction of $N$. pachyphylla is unknown, the strong climate cycles of the Pleistocene may well have been involved. The extinction of $N$. pachyphylla and the survival of $N$. cunninghamii are consistent with the overall pattern in the Regatta Point floras, which contain a mixture of extant and extinct rainforest species (Jordan 1992; 1995a,b; 1997a,b). This pattern explains in part the nature of diversity of the Tasmanian rainforest flora which is floristically poor, but which has a high number of endemic genera and species (Kirkpatrick and Brown 1984). The implication is that the rainforest flora has undergone considerable extinction, but little speciation during the Quaternary.

\section{Acknowledgments}

I thank Leonie Scriven for drawing my attention to the cuticular differences between the two fossil species and Robert Hill, Ray Carpenter, Richard Barnes, Andrew Rozefelds, Tim Brodribb and anonymous referees for discussion and comments on the manuscript.

\section{References}

Axelrod, D. A. (1988). An interpretation of high montane conifers in western Tertiary floras. Palaeobiology 14, 301-306.

Bresnehan, S. J. (1993). 'A Palaeobotanical Analysis of a Relict Lacustrine Deposit, Upper Mersey Valley, North Central Tasmania'. Unpublished honours thesis (Department of Geography, University of Newcastle: Newcastle.)

Bureau of Meteorology (1988). Climatic Averages: Australia. (Australian Government Publishing Service: Canberra.)

Carpenter, R. J. and Horwitz, P. (1988). Leaf litter in two southern Tasmanian creeks and its relevance to palaeobotany. Papers and Proceedings of the Royal Society of Tasmania 122, 39-45

Colhoun, E. A. and van der Geer, G. (1987). Pleistocene macro-and micro- plant fossils from Rosebery, western Tasmania. Papers and Proceedings of the Royal Society of Tasmania 121, 8992.

Colhoun, E. A., van der Geer, G., Hill, R. S. and Bird, T. (1989). Interglacial pollen and plant macrofossils from Langdon River, western Tasmania. New Phytologist 111, 531-48.

Dilcher, D. L. (1974). Approaches to the identification of angiosperm leaf remains. The Botanical Review 40, 1-157.

Fitzsimons, S. J., Colhoun, E. A., van der Geer, G. and Hill, R. S. (1990). Definition and character of the Regency Interglacial and Early-Middle Pleistocene stratigraphy in the King Valley, western Tasmania, Australia. Boreas 19, 1-15.

Fowler, A. J. (1993). 'A Late Pleistocene Forest at Coal Head Point, Macquarie Harbour, Tasmania'. Unpublished honours thesis (Department of Geography, University of Newcastle: Newcastle.)

Hickey, L. J. (1979). A revised classification of the architecture of dicotyledonous leaves. In 'Anatomy of the Dicotyledons, Vol. 1'. (Eds C. R. Metcalfe and L. W. Chalk.) pp. 25-39. (Clarendon Press: Oxford.)

Hill. R. S. (1991). Leaves of Eucryphia (Eucryphiaceae) from Tertiary sediments in South-eastern Australia. Australian Systematic Botany 4, 481-497. 
Hill, R. S. and Jordan, G. J. (1996). Macrofossils as indicators of Plio-Pleistocene climates in Tasmania and Antarctica. Papers and Proceedings of the Royal Society of Tasmania 130, 9-15 Hill, R. S. and Macphail, M. K. (1985). A fossil flora from rafted Plio-Pleistocene mudstones at Regatta Point, Tasmania. Australian Journal of Botany 33, 497-517.

Hill, R. S. and Read, J. (1991). A revised infrageneric classification of Nothofagus (Fagaceae) . Botanical Journal of the Linnean Society 105, 37-72.

Jordan, G. J. (1992). 'Macrofossil evidence for Quaternary Plant Extinction and Vegetation Change in Western Tasmania.' Unpublished PhD thesis (University of Tasmania: Hobart.)

Jordan, G. J. (1995a). Early Pleistocene leaves of extinct and extant Proteaceae from western Tasmania, Australia. Botanical Journal of the Linnean Society 118, 19-35.

Jordan, G. J. (1995b). Extinct conifers and conifer diversity in the Early Pleistocene of western Tasmania. Review of Palaeobotany and Palynology 84, 375-387.

Jordan, G. J. (1997a). Contrasts between the climatic ranges of fossil and extant taxa: causes and consequences for palaeoclimatic estimates. Australian Journal of Botany 45, 465-474.

Jordan, G. J. (1997b) Evidence of Pleistocene plant extinction and diversity from Regatta Point, western Tasmania, Australia. Botanical Journal of the Linnean Society 123, 45-71.

Jordan, G. J., Carpenter, R. J. and Hill, R. S. (1991). Late Pleistocene vegetation and climate near Melaleuca Inlet, south-western Tasmania. Australian Journal of Botany 39: 315-333.

Jordan, G. J. and Hill, R. S. (1994). Past and present variability in leaf length of evergreen members of Nothofagus subgenus Lophozonia related to ecology and populations dynamics. New Phytologist 127, 377-90.

Jordan G. J., Macphail M. K., Barnes R., Hill R. S. (1995). An Early-Middle Pleistocene flora of subalpine affinities in lowland western Tasmania. Australian Journal of Botany 43, 231-242.

Kershaw, A. P. and McGlone, M. S. (1995). The Quaternary history of the southern conifers. In 'Ecology of the Southern Conifers.' (Eds N. J. Enright and R. S. Hill.) pp 30-63. (Melbourne University Press: Melbourne.)

Kirkpatrick, J. B., and Brown, M. J. (1984 ). A numerical analysis of Tasmanian higher plant endemism. Botanical Journal of the Linnean Society 88, 165-83.

Macphail, M. K., Jordan, G. J. and Hill, R. S. (1993). Key periods in the evolution of the flora and vegetation in western Tasmania I. the Early -Middle Pleistocene. Australian Journal of Botany 41, 673-707.

Macphail, M. K., Colhoun, E. A. and Fitzsimons, S. (in press). Key periods in the evolution of the Cenozoic flora and vegetation in western Tasmania 2: The Late Pliocene. Australian Journal of Botany.

Manos, P. S. (1997). Systematics of Nothofagus (Nothofagaceae) based on rDNA spacer sequences (ITS): taxonomic congruence with morphology and plastic sequences. American Journal of Botany 84, 1137-1155.

Philipson, W. R. and Philipson, M. N. (1988). A classification of the genus Nothofagus (Fagaceae). Botanical Journal of the Linnean Society 98, 27-36.

Rowell, M. V. (1995). 'An in situ Pleistocene Fossil Forest from Coal Head, Macquarie Harbour, Tasmania'. Unpublished honours thesis (Department of Geography, University of Tasmania: Hobart.)

Scriven, L. J. and Hill, R. S. (1996). Relationships among Tasmanian Tertiary Nothofagus (Nothofagaceae) populations. Botanical Journal of the Linnean Society 121, 345-364.

Taylor, F. and Hill, R. S. (1996). A phylogenetic analysis of the Eucryphiaceae. Australian Systematic Botany 9,735-748.

Traverse, A. (1982). Response of world vegetation to Neogene tectonic and climatic events. Alcheringa 6, 197-209. 